\title{
The drowned woman
}

$\mathrm{T}$ here is a helicopter suspended over the waters of Peters Lake. I see it hanging there in the white sky, a dark insect, hunting. I watch it as I drive along the highway. When I turn off the road into the parking lot, the forest interposes itself and I lose sight of the helicopter. When I stop the car, though, I can hear its mechanical drone, the waffling beat of its blades as it hovers, searching. The sound is both ominous and forlorn.

I lock my car, walk up the hill to the apartment building, and climb the steps to the front entrance. The nurse is waiting for me, one hand raised to shield her eyes from the sun. I turn to follow her gaze toward the helicopter.

"They're looking for that woman," I say, unnecessarily.

She nods. We both stand for a moment, looking at the sky. A 54-year-old woman, missing since last Saturday when she was seen swimming alone. I don't need to point out to the nurse that it may have been a suicide: we both work in mental health, and the possibility is never far from our minds. Every person we meet, we wonder what the chances are. But that might not be what happened to the woman at all. It could have been an accident. All I know is what I've read in the papers.

"Did you bring the chart?" I ask.

"Right here," she says, patting her black briefcase. We turn from the helicopter and I open the glass door. There are neatly lettered names beside the buzzers, and the smell of the building is bleach and aging carpets, but mostly it's clean. The artificial plant is in need of dusting, but at least there's no cigarette butts shoved into its pot. Still, the building has seen better days.

The nurse rings the buzzer. We wait. She rings again.

"You called to say we were coming?" I ask.

"Yesterday," she says.

The way she says it suggests yester-

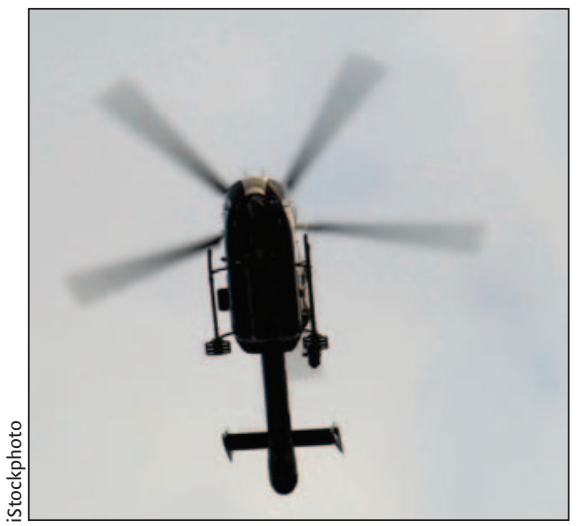

day can be a long time ago for our patient, who is somewhere in the moderate stage of dementia. She rings the bell again.

A young man in jeans comes in behind us, a tenant. He unlocks the door and lets us follow him in. He doesn't ask our business, but even if he did, we would probably make up a story about coming to see a friend. I couldn't tell him I'm a psychiatrist coming to see someone in the building. That would be a breach of confidentiality, and besides, it might make the other tenants nervous. Unnecessarily.

My patient's apartment is at the end of a long hallway. On the door is a grapevine wreath decorated with artificial sunflowers and a sign that reads "Welcome." We knock on the door. There is no response. We knock harder: still nothing. I press my ear against the door. Through the wood, I can hear the muffled, cheerful chatter of a television. I straighten up and try the doorknob: locked.

"Do you think she's in there?" I ask.

The nurse frowns. "I don't know where she could have gone. She never goes out by herself now."

I wonder if my patient has forgotten that a knock means you are supposed to come and see if there is someone standing in the hallway, waiting to come in. Or perhaps she is lost in her apartment, unable to find her way to the door. The last time I saw her, she was having more problems with her speech, and her unfocused indifference had been more marked. I press my ear up to the door again, and hear nothing.

The nurse gets a cell phone out of her purse and dials the patient's number. We stand there, listening to the telephone ringing inside the apartment.

"Do you think she's okay?" I ask. After all, she's nearly 80 years old. She could have fallen. Or worse. Two months ago, her apartment had been cluttered and disorderly. It should be better in there now: we called home care, and she's getting services on a regular basis. I'd been hoping to see the apartment and convince myself that she was still keeping her head above water. The call to adult protection hasn't yet been made, and I've been hoping to hold off for a while longer anyway

The nurse flips her cell phone closed. "If she's in there, she's not answering."

I look at the door, wishing I could see through it. "Do you think we should ask the superintendent to open it for us?"

"We can't do that without breaching confidentiality. And would he open it anyway?"

"We have no reason to think there's anything seriously wrong - do we?"

We talk like this for a few minutes until there is nothing more to say, and then we leave. It's very unsatisfactory. Even if there's nothing amiss, I won't be able to get back for several weeks for another visit. But the fact is, I can't shake that feeling of dread that something truly terrible has happened, or is about to happen.

At the top of the stairs I pause. I raise my eyes toward the sky where the helicopter is still hovering over the surface of the water, looking for the drowned woman.

\section{Lara Hazelton MD \\ Psychiatrist \\ Halifax, NS}

